\begin{tabular}{lcc}
\hline \multicolumn{3}{c}{ A N N A L E S } \\
UNIVERSITATIS MARIAE CURIE-SKŁODOWSKA \\
LUBLIN - POLONIA \\
VOL. XLVIII, 3 & SECTIO H \\
\hline
\end{tabular}

Uniwersytet Marii Curie-Skłodowskiej w Lublinie, Zakład Analiz Rynkowych

KATARZYNA MAMCARZ

Popyt na rynku złota

Market demand for gold

Słowa kluczowe: popyt na rynku złota, popyt na wyroby jubilerskie, popyt przemysłowy, popyt inwestycyjny

Key words: market demand for gold, jewellery demand, industrial demand, investment demand

\title{
Wstęp
}

Popyt na złoto, podobnie jak na szereg innych dóbr, jest determinowany przez wiele czynników. Są one zróżnicowane w zależności od motywów jego nabywania. Popularność tego metalu wynika stąd, że jak żadna inna klasa aktywów łączy w sobie równocześnie siedem cech, które są istotne z punktu widzenia podejmowania decyzji o jego zakupie: a) łatwość przenoszenia i transportu, b) łatwa rozpoznawalność, c) trwałość - nie podlega działaniu czynników atmosferycznych, związków chemicznych, itp., d) łatwa podzielność - formy różnych denominacji, np. sztaby, monety, e) wysoka wartość w stosunku do ciężaru i objętości, f) dobrowolna akceptowalność jako waluty światowej, g) urzekanie swoim pięknem i rzadkością [Bocker, 2010, s. 35-37]. Celem artykułu jest przeprowadzenie analizy popytu na rynku złota, ze szczególnym uwzględnieniem trzech głównych subkategorii popytu całkowitego: popytu na wyroby jubilerskie, przemysłowego oraz inwestycyjnego, a także czynników go kształtujących. 


\section{Przegląd rynku}

Złoto od dawna jest związane z ludzką cywilizacją. Mimo że w przyrodzie występuje stosunkowo rzadko, to zostało odkryte wcześniej niż inne metale. Jego znaleziska w Egipcie datuje się już na 4000 lat p.n.e. [Bergold, Eller, 2006, s. 56]. Popyt na ten metal szlachetny występuje na więcej niż jednym rynku. Wyróżnia się następujące główne rodzaje popytu na złoto: popyt na wyroby jubilerskie, popyt przemysłowy i medycyna, popyt inwestycyjny, inwestycje implikowane netto, popyt sektora urzędowego, popyt producentów złota, tzw. de-hedging. Wyroby jubilerskie oraz składniki popytu inwestycyjnego (sztabki, monety, medale oraz imitacje monet) są to fizyczne produkty złota [Starr, Tran, 2008, s. 416]. Informacje te przedstawiono w tabeli 1.

Tabela 1. Popyt światowy na złoto (w tonach) i średnia roczna cena złota (w USD/oz) w latach 2003-2012

\begin{tabular}{|c|c|c|c|c|c|c|c|c|}
\hline & \multirow{2}{*}{$\begin{array}{c}\text { Lata } \\
\text { Wyroby } \\
\text { jubilerskie }\end{array}$} & $\begin{array}{c}\text { Popyt } \\
\text { przemysło- } \\
\text { wy i me- } \\
\text { dycyna }\end{array}$ & $\begin{array}{c}\text { Popyt } \\
\text { inwesty- } \\
\text { cyjny* }\end{array}$ & $\begin{array}{c}\text { Inwestycyjny } \\
\text { impli- } \\
\text { kowane } \\
\text { netto** }\end{array}$ & $\begin{array}{c}\text { Popyt } \\
\text { sektora } \\
\text { urzędowe- } \\
\text { go netto }\end{array}$ & $\begin{array}{c}\text { De-hedging } \\
\text { producen- } \\
\text { tów netto }\end{array}$ & Razem & $\begin{array}{c}\text { Cena złota } \\
\text { (w USD/oz) }\end{array}$ \\
\hline 2003 & 2484 & 386 & 310 & 772 & - & 289 & 4241 & 363,32 \\
\hline 2004 & 2616 & 419 & 360 & 31 & - & 438 & 3864 & 409,17 \\
\hline 2005 & 2719 & 438 & 400 & 477 & - & 92 & 4126 & 444,45 \\
\hline 2006 & 2300 & 468 & 422 & 369 & - & 434 & 3994 & 603,77 \\
\hline 2007 & 2423 & 476 & 444 & 207 & - & 436 & 3968 & 659,39 \\
\hline 2008 & 2304 & 461 & 884 & 10 & - & 357 & 4015 & 871,96 \\
\hline 2009 & 1816 & 410 & 791 & 1130 & - & 234 & 4381 & 972,35 \\
\hline 2010 & 2020 & 465 & 1187 & 607 & 77 & 106 & 4462 & 1224,52 \\
\hline 2011 & 1975 & 452 & 1530 & 103 & 457 & - & 4517 & 1571,52 \\
\hline 2012 & 1893 & 407 & 1311 & 294 & 532 & 40 & 4477 & 1668,98 \\
\hline
\end{tabular}

* Popyt inwestycyjny obejmuje sztabki złota i wszystkie monety.

** Inwestycje implikowane netto są wartością rezydualną bilansującą dane odnośnie do podaży i popytu wg Thomson Reuters GFMS.

Źródło: [Gold Survey, 2013, tabela 1, s. 8; tabela 1A, s. 9].

Światowy popyt na złoto, mimo pewnych wahań w poszczególnych latach analizowanego dziesięciolecia, był jednak stosunkowo stabilny (przeciętnie rocznie wynosił 4204,5 tony, odchylenie standardowe 242,43 tony, współczynnik zmienności 5,77\%), 
podczas gdy cena wzrosła czterokrotnie. Co więcej, w niektórych latach kształtował się prawie niezależnie od ceny. Były lata, w których wraz ze wzrostem ceny złota obserwowano zarówno spadek, jak i zwiększenie popytu. Nie znaczy to, że na tym rynku nie działa prawo popytu i podaży. Opisana zależność ilustruje natomiast szczególną cechę złota, wyrażającą się tym, że w pierwszym rzędzie nie jest ono surowcem przemysłowym i przedmiotem codziennego zapotrzebowania. Stanowi przede wszystkim przedmiot luksusu, a także inwestycji i tylko w nieznacznym zakresie jest surowcem przemysłowym w ścisłym tego słowa znaczeniu. $Z$ tego punktu widzenia można wiele powiedzieć na temat złota, czy to kształtowania się jego ceny, czy popytu [Schwarze, 2010. s. 52].

Udział poszczególnych rodzajów popytu na złoto w popycie światowym jest dość zróżnicowany. Największy udział mają wyroby jubilerskie - w przedziale od $41,45 \%$ w 2009 r. do $67,70 \%$ w 2004 r. W ostatnich latach obserwuje się jednak spadek zainteresowania tymi wyrobami, związany z bardzo wysokimi cenami kruszcu. Drugie miejsce (od połowy analizowanego okresu niezagrożone) zajmował popyt inwestycyjny. Popyt na złoto ze strony przemysłu i medycyny był stosunkowo stabilny (przeciętny roczny popyt wyniósł 438,20 tony, odchylenie standardowe 30,93 tony, współczynnik zmienności 7,06\%). De-hedging producentów netto oznacza zakupy dokonywane przez kopalnie złota w celu zrealizowania wcześniej zawartych transakcji terminowych z obawy przed spadkiem cen kruszcu w przyszłości. W przypadku błędnej prognozy w tym zakresie kopalnie muszą nabyć złoto na rynku, stąd wysokie skoki zapotrzebowania. Wzrost popytu urzędowego w ostatnich latach wynikał ze zmian struktury portfeli banków centralnych, zwłaszcza w krajach rozwijających się, kosztem innych aktywów, w szczególności rezerw dolarowych [Gold Survey, 2013, s. 12]. W dalszej części poddano analizie trzy główne rodzaje popytu całkowitego: na wyroby jubilerskie, przemysłowy włącznie z medycyną oraz inwestycyjny.

\section{Popyt na wyroby jubilerskie}

O całkowitym popycie na wyroby jubilerskie decydują dwa czynniki, tj. cena i dochód. Determinują one równocześnie zapotrzebowanie na złoto ze strony branży jubilerskiej. Popyt na te wyroby reagował negatywnie na wzrost ceny od połowy analizowanego okresu. Branża jubilerska jest bardzo wrażliwa na cenę złota przede wszystkim w krajach słabo rozwiniętych. Wysoka cena powoduje, że ludność krajów biednych nabywa niewiele biżuterii lub w ogóle przestaje ją kupować. Również deprecjacja walut tych krajów powoduje wzrost ceny złota i ogranicza popyt. Dochód ma natomiast wpływ na popyt zarówno w krajach bogatych, jak i biednych. W tych pierwszych, gdzie biżuterię traktuje się jako przedmiot luksusu, popyt w zasadzie uzależniony jest od poziomu dochodów. Wszystkie zjawiska, które je pomniejszają, np. międzynarodowy kryzys finansowy, mają ujemny wpływ na całkowity popyt na wyroby jubilerskie. W krajach biednych takie zjawiska jak wysoka inflacja, masowe 
bezrobocie, nieurodzaje w rolnictwie obniżają także dochody i tym samym popyt na złoto. Niewątpliwie są również inne ważne czynniki decydujące o skali popytu na złoto jubilerskie (moda, liberalizacja rynku złota).

W tabeli 2 zaprezentowano wielkość i strukturę przestrzenną popytu na rynku wyrobów jubilerskich. Z danych wynika, że popyt w latach 2010-2012 zmniejszył się o 6,30\%. Z wyjątkiem krajów CIS (Commonwealth of Independent States, wzrost o 16,94\%) i Azji Wschodniej (wzrost o 5,91\%) obserwuje się spadek popytu na wyroby jubilerskie we wszystkich regionach świata, największy w Ameryce Łacińskiej (o 20,0\%). Udział poszczególnych regionów w popycie całkowitym był jednak zróżnicowany. Na kraje azjatyckie w 2012 r. przypadało aż 80,76\% popytu światowego. Sam subkontynent indyjski absorbował ok. 1/3 światowej produkcji złota. Udział pozostałych regionów był już niewielki. Znaczący odsetek w popycie całkowitym krajów Azji wynika stąd, że mieszka tam prawie połowa ludności świata, wzrasta dobrobyt klas średnich i tym samym ich siła nabywcza. Mieszkańcy Azji są ponadto znani ze swej skłonności do oszczędzania (do $40 \%$ dochodów do dyspozycji) [Bocker, 2010, s. 74]. Pogłębiona analiza popytu na wyroby jubilerskie wymaga także rozróżnienia między biżuterią inwestycyjną a biżuterią czysto ozdobną. W krajach Azji złoto, a przede wszystkim biżuteria są tradycyjnie traktowane jako inwestycja, symbol bogactwa, a także finansowe zabezpieczenie na przyszłość [Starr, Tran, 2008, s. 416, 418]. Wyroby jubilerskie pełnią tam inną funkcję niż w Europie i USA. Ten elemenent inwestycyjny biżuterii ma niewątpliwie wpływ na wielkość popytu. Decydujący jest tu czynnik kulturowy ${ }^{1}$. Resumując, wspomniany wcześniej wysoki udział popytu na rynku wyrobów jubilerskich w popycie całkowitym na złoto jest pochodną struktury popytu na rynku międzynarodowym, zdominowanym przez ludność krajów Azji.

Tabela 2. Wielkość i struktura popytu na wyroby jubilerskie wg regionów w latach 2010-2012

\begin{tabular}{|c|c|c|c|c|c|c|}
\hline \multirow{2}{*}{ Kontynent } & \multicolumn{3}{|c|}{ Popyt (w tonach) } & \multicolumn{3}{c|}{ Struktura popytu (w \%) } \\
\cline { 2 - 7 } & 2010 & 2011 & 2012 & 2010 & 2011 & 2012 \\
\hline Kontynent subindyjski & 723,2 & 700,0 & 649,6 & 35,80 & 35,44 & 34,32 \\
\hline Azja Wschodnia & 613,9 & 656,7 & 650,2 & 30,39 & 33,25 & 34,35 \\
\hline Bliski Wschód & 267,8 & 234,7 & 228,8 & 13,26 & 11,88 & 12,09 \\
\hline Europa & 204,0 & 182,8 & 169,8 & 10,10 & 9,26 & 8,97 \\
\hline Ameryka Północna & 75,3 & 69,0 & 61,9 & 3,73 & 3,49 & 3,27 \\
\hline
\end{tabular}

${ }^{1}$ Hindusi kupują złoto przede wszystkim w sezonie zawierania małżeństw, a nawet dla związków, które będą zawierane za 4-5 lat, jako ewentualny posag, w obawie przed oczekiwanym wzrostem cen [Bandulet, 2010, s. 186]. Złoto jest traktowane jako własność żony w przypadku ewentualnego rozwodu lub śmierci męża. Po rozwodzie może ona zabrać tyle biżuterii, ile jest w stanie na sobie unieść [Borowski, 2008, s. 181]. 
Pobrane z czasopisma Annales H - Oeconomia http://oeconomia.annales.umcs.pl Data: 26/04/2023 11:54:57

POPYT NA RYNKU ZŁOTA

\begin{tabular}{|c|c|c|c|c|c|c|}
\hline CIS & 60,2 & 67,4 & 70,4 & 2,98 & 3,41 & 3,72 \\
\hline Ameryka Łacińska & 50,5 & 41,8 & 40,4 & 2,50 & 2,12 & 2,13 \\
\hline Afryka & 22,2 & 19,8 & 19,0 & 1,10 & 1,00 & 1,00 \\
\hline Oceania & 3,2 & 2,9 & 2,8 & 0,16 & 0,15 & 0,15 \\
\hline Razem & 2020,2 & 1975,1 & 1892,9 & 100,00 & 100,00 & 100,00 \\
\hline
\end{tabular}

Źródło: opracowanie własne na podstawie [Gold Survey, 2013, tabela 8, s. 88-89].

\section{Popyt przemysłowy i medycyna}

Złoto znajduje wszechstronne zastosowanie w przemyśle i medycynie. Decydują o tym przede wszystkim jego cechy fizyko-chemiczne, tj. duża plastyczność, wysokie przewodnictwo ciepła i elektryczności, odporność na korozję, biologiczna obojętność. Nadaje się również do lutowania, łączenia z innymi metalami, łatwo wchodzi w stopy, dobrze odbija światło. Popyt przemysłowy można sprowadzić do trzech obszarów: przemysł elektroniczny, inne przemysły i dekoracje, medycyna [Schwarze, 2010, s. 61-66].

Najważniejszym obszarem zastosowania złota jest przemysł elektroniczny (warstwowanie i kształtowanie platyny), a także chemiczny (technologie galwaniczne). W sferze dekoracji używa się go do ozdabiania różnych przedmiotów tradycyjnych, przede wszystkim w przemyśle ceramicznym i szklarskim. Znajduje także zastosowanie jako złoto powierzchniowe do upiększania prestiżowych budynków, reprezentacyjnych pomieszczeń wewnętrznych, dzieł sztuki i książek. Dzięki swej fenomenalnej optyce i odporności na korozję spełnia funkcję farby zewnętrznej i stanowi efektowną dekorację. Jest także stosowane przy wytwarzaniu modnych ozdób i do upiększania przedmiotów wysokiej wartości do pisania (pióra, długopisy). Służy również do wyrobu przedmiotów luksusowych, takich jak oprawki okularów, sprzączki w paskach, zapięcia w torebkach. Całkowity popyt na złoto jako metal dekoracyjny determinują dwa czynniki. Z jednej strony wraz z rosnącą ceną wielu klientów szuka alternatywy dla prawdziwych ozdób ze złota, $\mathrm{z}$ drugiej strony znajduje zastosowanie w przemyśle do uszlachetnienia przedmiotów luksusu i popyt tego segmentu zależy od zamożności społeczeństwa danego kraju [Green, 1993, s. 352-354].

Pomimo zastosowań złota w wielu obszarach przemysłu zapotrzebowanie zgłaszane na nie ma niewielki udział w popycie całkowitym (ok. 10,0\%). Wynika to z wielu przyczyn. O rzadkości stosowania tego kruszcu w przemyśle przesądza jego wysoka cena, która musi być jednak akceptowana, ponieważ nie ma adekwatnego substytutu dla tego metalu. Ma on szereg istotnych, wspomnianych już właściwości chemicznych i fizycznych, które powodują, że nie można z niego zrezygnować. Spadek jakości produktu nie leży również w interesie wytwórców i klientów, zwłaszcza przy 
wartościowych produktach, gdy liczy się przede wszystkim ich jakość, a mniejsze znaczenie ma cena. $Z$ drugiej strony należy zauważyć, że złoto, pomimo wysokiej ceny, ma nieznaczny udział w ogólnych kosztach wytworzenia produktu końcowego. W wielu przypadkach sam proces produkcji jest znacznie droższy i wymaga więcej nakładów, niż wynosi koszt złota jako materiału. Dlatego popyt przemysłu w niewielkim stopniu zależy od ceny, charakteryzuje się niską elastycznością $(E=0,04$ w latach 2003-2012)2. Spadek popytu wiąże się również z innowacjami technicznymi. Pozwalają one osiągnąć ten sam efekt przy mniejszej ilości zużytego złota. Dla tak drogiego surowca próbuje się także szukać odpowiednich substytutów. Nie można jednak wykluczyć, że znajdą się nowe obszary dla zastosowania złota, co wpłynie na wzrost popytu. Popyt przemysłowy zależy również od koniunktury gospodarczej, gdy jest zła, maleje popyt na produkty z udziałem złota i wskutek tego zmniejsza się zapotrzebowanie przemysłu. Reasumując, występuje duża liczba przyczyn decydujących o skali popytu na złoto w przemyśle.

Zastosowanie tego kruszcu w medycynie ma miejsce głównie w stomatologii (koronki, wypełnienia, mostki, lutowanie). Ponieważ złoto jest miękkie, w większości przypadków stosuje się stopy, tzw. złoto dentystyczne, o zawartości złota między $62 \%$ i $78 \%$. Wykorzystanie tego metalu w medycynie dentystycznej jednak maleje. Wynika to z postępu techniki. Nowe materiały często są lepszym i tańszym substytutem. Z pewnością dużą rolę odgrywa także zmiana podejścia do estetyki. $\mathrm{W}$ medycynie złoto znajduje zastosowanie także w leczeniu artretyzmu oraz przy produkcji protez, ze względu na jego biologiczną obojętność. W latach 2003-2012 zużycie tego kruszcu w medycynie spadło z 67 do 39 ton [Gold Survey, 2013, s. 9].

\section{Popyt inwestycyjny}

Inwestorzy wybierający złoto kosztem np. tradycyjnych instrumentów finansowych i rezygnujący tym samym $z$ dochodów bieżących $w$ postaci dywidendy (akcje) lub odsetek (obligacje) czynią to $\mathrm{z}$ wielu powodów. U podstaw inwestycji w złoto leży kilka motywów: a) motyw bezpieczeństwa (zabezpieczenie majątku przed ryzykiem politycznym i gospodarczym), b) motyw zysku (spekulacja krótkoterminowa, inwestycja długoterminowa), c) motyw ograniczenia ryzyka kursowego (dywersyfikacja portfela), d) motywy emocjonalne (fascynacja złotem, symbol władzy i bogactwa ${ }^{3}$ ). Lokowanie kapitału w złoto fizyczne było od dawna tradycyjną możliwością inwestycyjną. Do kolejnego renesansu na rynku tego kruszcu doszło w 2000 r. Wynikało to z rosnącego braku zaufania inwestorów do rynku akcji, obaw przed inflacją, wyraźnego osłabienia dolara, a także większego ryzyka geopolitycznego. Spowodowało to uwzględnianie złota w portfelach inwestycyjnych.

\footnotetext{
2 Obliczenia własne na podstawie [Gold Survey, 2013, tabela 1A, s. 9].

3 Tę rolę złota trafnie wyraża przysłowie: „Gdy przemawia złoto, milczy cały świat” [Sieper, 1991, s. 273].
} 
W obrocie występuje ono zarówno w postaci czystej, jak i stopów. Domieszka innych metali ma na celu nadać mu inny kolor lub właściwości obróbcze, a niekiedy także pozwolić na zaoszczędzenie drogiego surowca. W popycie inwestycyjnym w aspekcie uczestnictwa inwestora we wzroście ceny złota istotna jest zawartość czystego kruszcu w stopie, tzw. próba złota.

Dane na temat całego popytu inwestycyjnego na złoto opierają się na szacunkach, ponieważ duża jego część realizowana jest na wyjątkowo nieprzejrzystym rynku pozagiełdowym. Także zakupy w handlu detalicznym nie mogą być w pełni dokładne. W literaturze mówi się o trudno identyfikowanym popycie inwestycyjnym, przy czym za taki uważa się jednoznacznie wszystkie zakupy złota, z wyjątkiem aktywności banków centralnych [Schwarze, 2010, s. 66]. W związku z długą historią złota jest wiele produktów, za których pośrednictwem metal ten wchodzi na rynek. Nie wszystkie jednak spełniają wymóg inwestycji lub - precyzyjnie - tylko niektóre z nich umożliwiają inwestorom uczestniczenie w pełnym zakresie we wzrostowym trendzie ceny złota. Jako przedmiot popytu inwestycyjnego w rachubę wchodzą fizyczne produkty złota (sztabki, monety urzędowe, medale) oraz fundusze inwestycyjne bazujące na złocie (ETF-y i zbliżone produkty) - w całości spełniające kryterium inwestycji, warunkowo mogą być to także wyroby jubilerskie, złoto dentystyczne, przedmioty sztuki.

Całkowity popyt inwestycyjny na sztabki, różne monety i medale, w odróżnieniu od popytu na wyroby jubilerskie, zwiększał się cały czas, w ostatnich latach nawet gwałtownie, wraz ze wzrostem ceny złota. O ile w 2003 r. wyniósł 310 ton, to w $2011 \mathrm{r}$. było to już 1530 ton, a w 2012 r. 1311 ton. Dopiero w ostatnim roku obserwuje się spadek popytu. Jego wcześniejszy wzrost i wysoka cena kruszcu były wyrazem słabości innych klas aktywów i walut. Załamanie całego systemu finansowego w $2008 \mathrm{r}$. skutkowało bowiem powstaniem państwowych programów ratunkowych, kosztujących biliony dolarów, mających ustrzec przed bankructwem instytucje kredytowe. W tej sytuacji złoto stało się znacznie bardziej atrakcyjną inwestycją. W rezultacie doszło do niewiarygodnego boomu na rynku złota fizycznego (sztab i monet). W Europie i w USA ten rynek charakteryzował się wąskimi gardłami i opóźnieniami po stronie podaży i nieznaną wcześniej skalą popytu. Mogło to wynikać również stąd, że tak gwałtownie rosnące ceny zwróciły uwagę inwestorów na rynek złota. Ponadto zakładali oni, iż koniec hossy jeszcze długo nie zostanie osiągnięty i wejście na rynek nawet przy wysokich cenach nadal im się opłaci.

Istotne miejsce $\mathrm{w}$ światowym popycie inwestycyjnym zajmują fizyczne produkty złota (rysunek 1). Z danych wynika, że popyt podążał za wzrostem ceny w przypadku trzech produktów złota fizycznego, abstrahując od przejściowych załamań w niektórych latach. Najwyższy udział w strukturze popytu miały sztabki (od 54,05\% w 2007 r. do $78,24 \%$ w 2011 r.) przed monetami urzędowymi (od 15,26\% w 2012 r. do $34,52 \%$ w 2003 r.) oraz medalami i imitacjami monet (od 5,75\% w 2011 r. do 15,32\% w 2007 r.).

W kontekście wysokiej stopy zwrotu polecaną inwestycją na rynku złota są sztabki. Ich zaletą jako inwestycji są relatywnie niskie koszty wytworzenia. Obowiązuje 
tu następująca reguła: im mniejszy ciężar sztabki, tym większy jest udział kosztów bicia w kosztach całkowitych i tym wyższa premia w stosunku do wartości czystego metalu [Sieper, 1991, s. 278]. Inwestorzy powinni nabywać sztabki od wytwórców, którzy spełniają wymogi Good Delivery Standard, gdyż tylko te dają gwarancję niezakłóconego obrotu na rynku złota. Oferowane są przez znanych światowych producentów, takich jak: Argor-Heraeus, Heraeus, Umicore (wcześniej Degussa) lub Pamp Suisse. Oferują oni sztabki różnej wielkości oraz liczne ich rodzaje: sztabki z motywami, pamiątkowe, wisiorki, kwadratowe, owalne, okrągke oraz w formie serc. Większość takich sztabek pochodzi z produkcji europejskiej i dysponuje stemplem mennicy wymienionych już, znanych producentów ${ }^{4}$. Na sztabkach zawsze są wybite dane na temat ciężaru i zawartości złota oraz nazwa lub logo wytwórcy. Przy sztabkach standardowych do tej listy danych dodawane są numer serii i rok produkcji. Właśnie przy sztabkach inwestorzy powinni szczególnie uwzględniać ich wagę. W przypadku dużych, mniejsza jest różnica między ceną kupna i sprzedaży, a więc nadają się do spekulacji. Małe sztabki wykazują natomiast wyższy spread i w ciężkich czasach mogą służyć jako środek wymiany [Nauckhoff, 2011, s. 170].

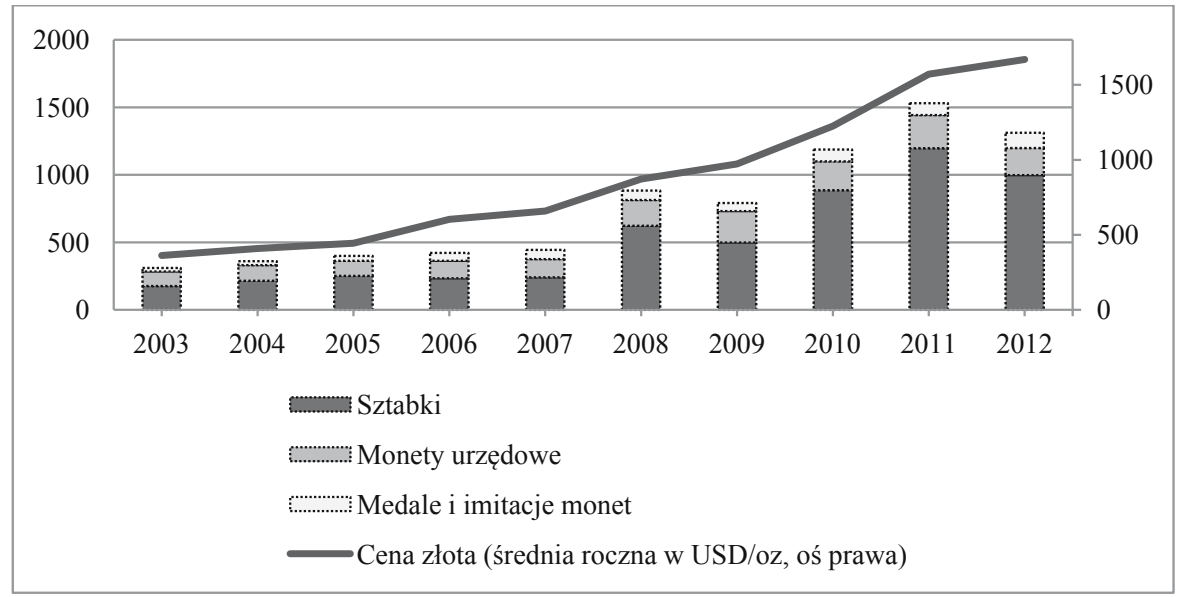

Rysunek 1. Zidentyfikowany popyt inwestycyjny (w tonach) oraz cena złota (w USD/oz) w latach 2003-2012

Źródło: opracowanie własne na podstawie: [Gold Survey, 2013, s. 9].

Gwałtownego wzrostu popytu na sztabki od połowy analizowanego okresu nie da się wyjaśnić inaczej jak tylko paniką. Nie można bowiem odnieść go w żaden sposób do cen złota. Omawianą sytuację dobitnie ilustruje zmiana w popycie na

\footnotetext{
${ }^{4} \mathrm{Na}$ Środkowym Wschodzie, w Indiach, Pakistanie i Singapurze są to sztabki tolas (1 tola = 11,64 grama $=0,375$ uncji), a w Chinach, na Tajwanie i w Hongkongu sztabki taels $(1$ tael $=37,429$ grama = 1,203 uncji), 1/2 tael 10 taels, w Tajlandii sztabki 10 baht (1 baht = 15,224 grama =0,4901 uncji). W Wietnamie spotyka się sztabkę chi (1 chi=3,75 grama =0,121 uncji) [Schwarze, 2010, s. 142; Sieper, 1991, s. 276]. Na rynku polskim występuje 7 rodzajów sztabek - o ciężarze 5 g, 10 g, 20 g, 31,1 g, 50 g, 100 g, 250 g [Borowski, 2008, s. 181].
} 
sztabki w krajach bogatych. O ile w 2003 r. w Europie inwestorzy przeprowadzali dezinwestycje (5,9 ton), a popyt w USA wyniósł 2,1 ton, to w 2012 r. popyt wzrósł już do 231,5 ton (Europa) i 18,5 ton (USA) [Gold Survey, 2013, s. 35]. W okresie kryzysu finansowego i późniejszym inwestorzy zaczęli obawiać się o bezpieczeństwo swoich aktywów w formie innej niż złoto.

Ze zwiększeniem popytu na sztabki wiązał się wzrost popytu na monety. Oprócz zakupów monet dokonywanych przez inwestorów instytucjonalnych zainteresowanie zaczęli zgłaszać również inwestorzy indywidualni, w tym drobni inwestorzy w krajach biednych. W latach 2003-2012 popyt na monety wzrósł, np. w USA o 73,9\%, w Wielkiej Brytanii o 130,0\%, w Chinach o $398,0 \%$, a w RPA o 717,2\% [Gold Survey, 2013, tabela 3, s. 37]. Świadczy to o dużej popularności monet jako formy inwestycji w złoto.

Wyróżnia się monety numizmatyczne, półnumizmatyczne, kuranty oraz bulionowe [Sieper, 1991, s. 278]. Monety numizmatyczne stanowią przedmiot kolekcjonerstwa. O ich wartości decyduje wiele czynników: wielkość emisji, rzadkość, wiek, stan zachowania, wizerunek na monecie, mennica. Monety półnumizmatyczne nie są tak rzadkie jak numizmatyczne i dlatego osiągają niższe ceny. Nabywcy płacą za wymienione monety ceny umowne (uznaniowe), które znacznie przekraczają wartość czystego metalu. Jest to obarczone pewnym ryzykiem i dlatego nie nadają się one jako czysta inwestycja kapitałowa. W pewnej mierze dotyczy to również monet kurantowych. Są to monety historyczne, które podczas obowiązywania systemu pieniądza złotego były prawnym środkiem płatniczym ${ }^{5}$. Numizmatyka nie ma jednak wiele wspólnego z profesjonalną strategią inwestycyjną. W monetach wartość metalu odgrywa rolę drugorzędną, a istotna jest ich wartość kolekcjonerska. W przypadku doświadczonych kolekcjonerów może dojść nawet do powstania szarej strefy. Wymienione monety nie są raczej polecane jako przedmiot inwestycji [Schwarze, 2010, s. 134].

Za klasyczne monety inwestycyjne ogólnie uważa się monety bulionowe (nowe lub kolejne emisje), określane także mianem monet sztabkowych. Większość mennic dostosowuje swoją paletę produktów do potrzeb inwestorów i oferuje monety bulionowe o różnych nominałach. Wybita wartość nominalna ma raczej charakter symboliczny i w pewnym sensie stanowi gwarancję najniższej ceny. Cenę monet bulionowych określa bowiem bezpośrednio wartość zawartego w nich złota oraz premia, która jest relatywnie niska i zależy od kosztów bicia. Różnica między ceną rynkową monet bulionowych a ich wartością nominalną jest najczęściej tak duża, że ta druga nie ma większego znaczenia dla inwestycji. Są one przedmiotem obrotu rynkowego. Większość inwestorów nabywa monety bulionowe z zamiarem otrzymania wysokich stóp zwrotu $\mathrm{z}$ inwestycji, a także w celu zachowania wartości, nieraz również traktują je jako gwarancję bezpieczeństwa. W przypadku pierwszego motywu inwestorzy zakładają

\footnotetext{
${ }^{5}$ Za monety numizmatyczne uważane są wszystkie emisje z czasów Napoleona, a za półnumizmatyczne monety z okresu 1804-1850. Najbardziej znane monety kurantowe to 20 marek niemieckich (Preußen Wilhelm II) i szwajcarska vreneli o zawartości czystego złota 900/1000 [Sieper, 1991, s. 278].
} 
ewentualną sprzedaż. Przedmiotem inwestycji powinny być monety, które nabywca może sprzedać w każdym czasie i w każdym miejscu. Gwarancją wiarygodności i zawartości złota w monecie jest prawidłowy stempel menniczy.

W zależności od regionu świata istnieje różna akceptacja monet bulionowych. Dla inwestorów europejskich światową akceptację ma wiele z nich: południowoafrykański krügerrand, amerykański złoty orzeł (American Gold Eagle), kanadyjski liść klonu (Gold Maple Leaf), meksykańska bogini zwycięstwa (Libertad), brytyjska Britannia in Gold, brytyjski suweren (Britsh Gold Sovereign), australijski kangur (Kangaroo) albo inaczej bryłka (Nugget), wiedeńscy filharmonicy (Wiener Philharmoniker), rosyjskie ruble. Powodzeniem cieszą się również chińska panda i australijski lunar [Green, 1993, s. 314; Sieper, 1991, s. 279; Ostrowska, 2011, s. 210].

Medale są monetami zawierającymi złoto lub emisjami pamiątkowymi bez wartości nominalnej, które nie były i obecnie nie są oficjalnym środkiem płatniczym. Mają one z reguły zawyżoną wartość i nie stanowią praktycznie przedmiotu obrotu na rynku wtórnym, co utrudnia ich sprzedaż. Sprzedając je, inwestor otrzymuje z reguły ułamek tego, co wcześniej zapłacił. Dlatego nie powinny wchodzić w rachubę jako rentowna inwestycja [Schwarze, 2010, s. 134].

W przypadku popytu inwestycyjnego należy stwierdzić, że zasadniczo istnieje relatywnie wysokie bezpieczeństwo inwestycji w złoto fizyczne. W warunkach kryzysowych pozwala ono zachować wartość majątku i zbilansować ryzyko wynikające z innych aktywów, ponieważ jego cena jest ujemnie skorelowana $\mathrm{z}$ ich ceną. Przy fizycznej inwestycji w złoto inwestorzy zainteresowani wysoką stopą zwrotu uczestniczą bezpośrednio w zmianach jego ceny, podczas gdy bezpieczeństwo jest pożądanym dla nich efektem ubocznym. Wielu inwestorów preferuje również inwestycje w złoto fizyczne, ponieważ w przeciwieństwie do niektórych innych produktów finansowych nie powstają tu zobowiązania wobec osób trzecich. Długofalowa fizyczna inwestycja w ten kruszec powinna być zatem istotną częścią każdego profesjonalnego portfela.

\section{Zakończenie}

Specyfika popytu na rynku złota wyraża się w tym, że jest on zgłaszany na kilku subrynkach, zwłaszcza na subrynku produktów złota fizycznego. Popyt całkowity na złoto, mimo pewnych wahań w poszczególnych latach analizowanego dziesięciolecia, był jednak stosunkowo stabilny. Najwyższy udział w nim miały wyroby jubilerskie, w dalszej kolejności sztabki i monety oraz przemysł i medycyna. O skali popytu decydowało wiele czynników zarówno o charakterze ekonomicznym, jak i emocjonalnym, psychologicznym, a także kulturowym. Wynika to z roli złota, które może być przedmiotem luksusu, surowcem przemysłowym, gwarancją bezpieczeństwa oraz instrumentem lokaty kapitału. Istotnym czynnikiem decydującym o skali rynkowego popytu jest cena. W przypadku popytu na złoto oczywista zależność tych dwóch kategorii ekonomicznych nie była jednak jednoznaczna. W niektórych latach 
obserwowano równoczesny wzrost ceny i popytu na złoto. Jest to istotny dowód empiryczny na szczególne znaczenie złota oraz innych, poza ceną, motywów, którymi kierują się inwestorzy przy jego nabywaniu.

\section{Bibliografia}

1. Bandulet B., Das geheime Wissen der Goldanleger, Kopp Verlag, 3. Auflage, Rottenburg 2010.

2. Bergold U., Eller R., Segmentierung der Assetklasse: Rohstoffe, [w:] U. Bergold, R. Eller, Investmentstrategien mit Rohstoffen, Wiley-VCH Verlag, Weinheim 2006.

3. Bocker H., Liberty through Gold, 3rd Edition, Johannes Müller, Bern 2010.

4. Borowski K., Rynek zlota i monet, [w:] I. Pruchnicka-Grabias, Inwestycje alternatywne, CeDeWu, Warszawa 2008.

5. Gold Survey, Thomson Reuters GFMS, London 2013.

6. Green T., The world of gold, Rosendale Press, London 1993.

7. Nauckhoff M., Strategische Metalle und Seltene Erden, 2. Auflage, FinanzBuch Verlag, München 2011.

8. Ostrowska E., Portfel inwestycyjny klasyczny i alternatywny, Wydawnictwo C.H. Beck, Warszawa 2011.

9. Schwarze N., Investieren in Gold, 1. Auflage, FinanzBuch Verlag, München 2010.

10. Sieper H., Geldanlage professionell, Gabler Verlag, Wiesbaden 1991.

11. Starr M., Tran K., Determinants of the Physical Demand for Gold: Evidence from Panel Data (July 1, 2007) "World Economy" 2008, vol. 31, no. 3.

\section{Market demand for gold}

Market demand for gold is characterized by particular specificity, which is that there are several submarkets in this market, a significant position being occupied by demand markets for physical gold. The scale of demand in these markets is determined by a number of economic and emotional, psychological, and cultural factors. This stems from the role of gold, which can be a luxury object, industrial raw material, a guarantee of security, and an instrument of investment. A vital factor that determines the scale of market demand is the price. In the case of the demand for gold, the evident relationship between the two economic categories has not been clear-cut, however. This is an essential empirical proof of the special importance of gold, and other motives, apart from price, that govern investors when buying it. 